\title{
О ВКЛАДЕ БЫВШЕГО ДИРЕКТОРА БЕЛГОРОДСКОГО И ВОРОНЕЖСКОГО УЧИТЕЛЬСКИХ ИНСТИТУТОВ А.К. ДИМИТРИУ (1857-1925) В ВИЗАНТИНИСТИКУ
}

\author{
ㄷ Владимир Михайлович МОСКОВКИН, Марина Владимировна САДОВСКИ \\ ФГБОУ ВО «Белгородский государственный национальный исследовательский университет» \\ 308015, Российская Федерация, г. Белгород, ул. Победы, 85 \\ E-mail: moskovkin@bsu.edu.ru
}

\begin{abstract}
Аннотация. Рассмотрен научный вклад бывшего директора Белгородского и Воронежского учительских институтов Алексея Константиновича Димитриу (1857-1925) в византинистику. В результате анализа литературных источников показана значимость работ А.К. Димитриу, посвященных договорам русских с греками и труду Прокопия Кессарийского «Тайная история», на которые до сих пор ссылаются крупнейшие ученые - византинисты и специалисты по истории Древней Руси. Изучены труды известных исследователей по истории Древней Руси и Византии А.М. Введенского, М.Б. Свердлова, А.Н. Сахарова, А. Готлиба. Особое внимание уделено фундаментальному труду А.К. Димитриу, опубликованному в Одессе в 1894 г. и посвященному «Тайной истории» Прокопия Кесарийского - крупнейшего историка ранней византийской эпохи. Подчеркнута важность вышеуказанной работы А.К. Димитриу, состоящей в том, что через четыре года после ее выхода в свет она цитировалась в статье А. Готлиба «Прокопий, историк», напечатанной в Энциклопедическом словаре Ф.А. Брокгауза и И.А. Ефрона. Изучение опубликованных исследований и архивных данных показало, что научными руководителями А.К. Димитриу являлись крупнейшие византинисты того времени, профессора Ф.И. Успенский и Э.Р. фон Штерн.

Ключевые слова: А.К. Димитриу; Белгородский учительский институт; Воронежский учительский институт; византинистика; договора Руси с Византией; Прокопий
\end{abstract}

В работе [1] был в первом приближении изучен вклад Алексея Константиновича Димитриу в византинистику в контексте увековечивания его памяти в Белгороде и Воронеже. А.К. Димитриу был директором Белгородского учительского института с 1906 по 1913 г. и директором Воронежского учительского института с 1913 по 1918 г. [2-4]. По сравнению с работой [1] в настоящей статье будут приведены дополнительные источники [5; 6], в которых имеются ссылки на труды А.К. Димитриу [7; 8]. Наиболее подробно будет изучена монография А.Н. Сахарова [9], которая учитывалась в контент-анализе работы [1]. В этой монографии дан наиболее тщательный анализ работы А.К. Димитриу $[7 ; 8]$.

По сравнению с работой [1] нам удалось идентифицировать два новых источника, в которых идут ссылки на труд А.К. Димитриу $[7 ; 8]$.

В фундаментальном исследовании А.М. Введенского по договорам русских с греками, результаты которого были опубликованы в 2006 г. под эгидой Института русской литературы РАН [5], по поводу статьи [7] сказа- но: «Тексты договоров, заключенных Византийской империей с другими государствами, в частности с русскими, начали изучаться еще в XVIII веке. Для восстановления формы договорных грамот исследователи прибегали к сохранившемуся греко-персидскому договору 628 г. А.К. Димитриу добавил к нему также греко-венецианские договоры XI-XII веков».

М.Б. Свердлов на странице 140 своей обширной монографии по истории Домонгольской Руси [6] остановился на следующих выводах работы А.К. Димитриу [7, с. 10, 20]: «Исходя из содержания византийско-венецианских договоров, сохранившихся в венецианском архиве и содержащих обязанности империи по отношению к республике, А.К. Димитриу (в развитие идей и И.Ф.Г. Эверса [10] и С.А. Гедеонова [11]) отметил, что в летописи находится копия текста, составленного от имени Игоря к империи. Поэтому текст 944 г. содержал обязанности русских. Отсюда А.К. Димитриу сделал вывод, что византийского экземпляра по отношению к Руси у летописца не было. По его мнению, он погиб к тому времени, 
когда создавалась летопись, а летописец пользовался сделанными в Константинополе копиями договоров с греческих оригиналов, неутвержденного, по его мнению, в 911 г. и договора 944 г. от имени Игоря к Византии, тогда как в 907 г. был заключен словесный мир без письменного договора». Ссылки на работы И.Ф.Г. Эверса и С.А. Гедеонова сделаны нами.

Но наибольшее внимание этому фундаментальному труду А.К. Димитриу уделил А.Н. Сахаров в своей монографии по дипломатии Древней Руси [9]. Ниже мы приведем все заимствования из этой работы, чтобы показать фундаментальность труда А.К. Димитриу [12].

В параграфе 1 «Историографии вопроса о договоре 907 г.» главы 3 «Русско-византийский договор 907 г.» он пишет: «Другая группа ученых - как дореволюционных, так и советских - не отрицает достоверности летописных сведений о договоре 907 г., но считает его прелиминарным миром, который был перезаключен в 911 г.» [7, с. 543; 13, с. 135; 14 ; 15 , с. $296-297$; 16 , с. 10,$15 ; 17$, с. 311$]$.

В параграфе 5 «Историческое значение договора 901 г.» этой главы рассмотрен вопрос об «умолчании» источников в договоре 907 г.

Приведем следующий большой кусок из этого параграфа: «Если византийские источники действительно не упоминают об этом заурядном в византийской истории событии очередном приходе русской рати под стены Константинополя, возобновлении с Русью мирных отношений, ряде уступок Руси, являвшихся весьма традиционными в отношениях Византии с «варварским» миром, то русская летопись не только не умалчивает об этом, но буквально заполнена сообщениями о договоре 907 г. Красной нитью проходит мысль о нем через последующие соглашения и тексты, повествующие о новых военных конфликтах и мирных переговорах с империей. На эту черту русской летописи исследователи давно обратили внимание и, как это случилось с оценкой похода и договора 907 г., сразу же разошлись во мнениях. Одни (А.К. Димитриу [7, с. 546-547], В.И. Сергеевич $[18$, с. 635$]$, А.А. Шахматов [19, с. 58], М.Д. Приселков [20, с. 100]) считали, что в этих случаях летописец имел в виду любой иной договор кроме соглашения 907 г.»; дру- гие (А.В. Лонгинов [21, с. 77-78], Д.Я. Самоквасов $[22$, с. $5,16,29])$ полагали, что речь могла идти только о договоре 907 г.

В параграфе 6 «Равно другаго свещания и появление на Руси системы предварительных переговоров» третьей главы приводится ряд соображений по поводу сомнений А.А. Шахматова и целой группы ученых относительно достоверности договора 907 г. в связи с фразой договора 911 г.: «Равно другаго свещания...». По этому поводу мы заимствовали следующий большой кусок из этого параграфа: «Высказывая свою точку зрения, А.А. Шахматов не обратился к предшествующей историографии. Между тем уже в течение полутораста лет на страницах русских исторических трудов шла полемика по поводу первой фразы договора 911 г. Собственно полемики, как таковой, не было, просто каждый из историков, касавшихся этого вопроса, переводил данный текст по-своему. Эти переводы свелись к двум основным позициям: одни переводили фразу как «копия (список) с другого договора», то есть с самого договора 911 г., и рассматривали ее в качестве удостоверения, определяющего соответствие этого документа его первооснове византийскому хрисовулу или русскому переводу с греческой грамоты, написанной от имени русского великого князя; другие считали, что в этой фразе говорится о предшествующей договоренности, или договоре; в соответствии с этим перевод выглядел так: «Согласно другому договору, бывшему при...». Первым точку зрения о копии-списке высказал в 1852 г. И.И. Срезневский [23, с. 314]. Он полагал, что слово «равно» означает копию, противень другого договора. Затем данная версия была поддержана Н.А. Лавровским [24, с. 9, 43-44, 52], С.А. Гедеоновым [11, с. 57], Н.П. Ламбиным [25], а на исходе XIX века А.К. Димитриу [7; 8]».

Теперь перейдем к русско-византийскому договору 911 г. В параграфе 1 «Историография вопроса» главы 4 «Русско-Византийский договор 911 г.» особо отмечается, что: «новый этап в изучении русско-византийских договоров 911 и 944 г. связан с выходом в свет в 1895 г. статьи А.К. Димитриу «К вопросу о договорах русских с греками» и в 1904 г. книги А.В. Лонгинова «Мирные договоры русских с греками, заключенные в $\mathrm{X}$ веке». В этих работах линия сравнительно- 
исторического анализа русско-византийских договоров с другими дипломатическими соглашениями раннего средневековья получила яркое раскрытие, хотя в позициях обоих авторов есть существенное отличие. А.К. Димитриу впервые в отечественной историографии высказал мысль о том, что руссковизантийский договор 911 г. по всей вероятности был просто-напросто типичным хрисовулом византийского императора». Далее указывается, что А.К. Димитриу «пришел к такому выводу на основании изысканий немецкого византиниста К. Неймана, который проанализировал договоры, позднее заключенные Византией с итальянскими государствами - Венецией и Пизой. Именно К. Нейман первым заметил, что в X-XII веках в византино-иностранных соглашениях перечислялись обязательства лишь одного государства - Византии. Эти документы, идущие со стороны империи, получили форму хрисовула. Об обязательствах же другой стороны в этих соглашениях упоминалось лишь в общих чертах».

Другим источником для размышлений А.К. Димитриу, отмечает А.Н. Сахаров, явилось уже упоминаемое им греко-персидское соглашение [9]. Он пишет: «Вот эти-то документы А.К. Димитриу и называет «типическими» для византийской дипломатии. С этих позиций он оценивает и русско-византийские договоры. Они, по его мнению, были следствием «византийской дипломатической рутины», являлись типичными переводами с греческого и представляли собой «вполне надежный текст второй руки», то есть копии со вторых экземпляров договоров, тех самых экземпляров, которые подписывались греческой стороной, переводились и передавались русским. В связи с этим А.К. Димитриу характеризует договор 911 г. как развернутый формальный межгосударственный договор, ради заключения которого послы Олега отправились в Константинополь. Однако он полагал, что этот договор никогда не вступал в действие, так как его оформление, если исходить из сравнения с другими подобными же соглашениями, не было завершено. Византийские послы не появились в Киеве. Олег умер до ратификации договора. Хрисовул, где были изложены обязательства Византии по отношению к Руси, так и не был вручен, и грамота 911 г. осталась лишь как след промежуточных переговоров, которые так и не дошли до стадии межгосударственного оформления [7, с. 540, 542, 545].

В параграфе 1 «Обзор источников и историография вопроса» главы 6 «Русско-Византийский договор 944 г.» отмечается, что принципиальная позиция А.К. Димитриу о русско-византийских договорах была изложена выше, а по поводу конкретного соглашения 944 г. сказано: «Соглашение 944 г. он рассматривал как вид императорского хрисовула, однако полагал, что сам хрисовул не сохранился, а до нас дошла лишь отдельная хартия, идущая от русской стороны к грекам. Договор 944 г. А.К. Димитриу трактовал как выгодный для империи. Он подчеркивал, что текст этого документа проще и понятнее, чем текст соглашения 911 г., и объяснил это более высоким уровнем перевода [7, с. 540, $542,545,549-550]$.

В параграфе 2 «Обострение руссковизантийских отношений в середине $30-\mathrm{x}$ гг. X века. Война 941-944 гг. и переговоры на Дунае» А.Н. Сахаров отмечает, что не менее значительным аргументом является и постоянное наличие идеи дани при описании автором «Повести временных лет» всех известных русско-византийских конфликтов (в 907, 944, 970-971 гг.), на что уже были отсылки в главе, посвященной русско-византийскому договору 907 г. Эта идея присутствовала неизменно не только в отношениях Византии и Руси, но и в отношениях империи с Персией, Арабским халифатом, Болгарией и другими государственными образованиями второй половины I тысячелетия н. э. и нашла яркое отражение в договорах, заключенных Византией с сопредельными странами, как отмечает автор работы [1].

В этой связи он обращает внимание на его разногласия с некоторыми историками по вопросу о ежегодной дани, который стоял во время переговоров 944 г.: «В свое время А.К. Димитриу писал, что греки на Дунае предложили Игорю «выкуп». Б.Д. Греков также отметил, что греки предложили Игорю «выкуп», после чего и был заключен договор 944 г. [7, с. $453 ; 16 ; 26$, с. 453]. Он также не может согласиться с мнением А.К. Димитриу, будто «о каких-нибудь переговорах, клонившихся к заключению договора или напоминавших о заключенных уже договоpax, - ни слова» [7, с. 545; 27, с. 84]. В этой связи он пишет: «Как раз на Дунае были 
проведены именно такие переговоры. Они положили конец войне 941-944 гг. В ходе этих переговоров стороны апеллировали к условиям о выплате дани, установленным договором 907 г. И неслучайно через некоторое время в Киеве появилось греческое посольство. Договоренность о процедуре выработки нового русско-византийского соглашения - и это можно утверждать вполне определенно - также была достигнута во время этого первого тура мирных переговоров».

Из вышеизложенного можно заключить, что А.Н. Сахаров в своей монографии уделил большое внимание труду А.К. Димитриу [9], полемизируя с ним.

Другой фундаментальный труд А.К. Димитриу, опубликованный в Одессе в 1894 г. [8], был посвящен «Тайной истории» Прокопия Кесарийского, важнейшего историка ранней византийской эпохи. О важности этой работы А.К. Димитриу говорит тот факт, что через четыре года после ее выхода в свет она цитировалась в статье А. Готлиба «Прокопій важнейшій историк ранней византійской эпохи...», напечатанной в «Энциклопедическом словаре Ф.А. Брокгауза и И.А. Ефрона» $[11 ; 28 ; 29]$. Ниже приведем достаточно обширный фрагмент текста из этой статьи, чтобы понять суть споров по поводу вышеуказанного сочинения Прокопия, которое также называлось Anecdota.

«Со времени первого издания "Anecdota” (Alemannus, 1623) до последнего времени в ученой литературе не прекращался спор о достоверности содержания этого трактата и об авторских правах Прокопия. Так как в этом споре приняли участие католические патеры и их противники протестанты, а потом к ним присоединились и юристы, то спор принял тенденциозный характер. Паписты отстаивали достоверность "Anecdota" из нерасположения к одной из крупнейших фигур православного Востока; протестанты оппонировали им под давлением реформационной борьбы; юристы из преклонения перед законодательным и политическим гением Юстиниана с негодованием отвергали резкие и часто грязные разоблачения. Alemannus, Ш. Монтескье, Э. Гиббон, В.С. Тейфель стояли за подлинность "Anecdota" и достоверность приводимых там фактов. К этому направлению примкнул лучший исследователь Прокопия Ф. Дан. В своей обширной монографии о Прокопии, основанной на детальном изучении фактов и сравнительной критике всех приписываемых Прокопию сочинений, а также служившего ему образцом Фукидида, Ф. Дан приходит к выводу, что ни факты, несмотря на видимый контраст, ни язык в «Анекдотах» и «Историконе» не расходятся. Преувеличения «Анекдотов» объясняются, по его мнению, страстным характером историка (так думал и Э. Гиббон). Менее удачна попытка Л. Ранке рассматривать "Anecdota" как компиляцию, в которой некоторые части принадлежали самому Прокопию, а другие заимствованы из появившегося после смерти Юстиниана Великого памфлета, выражавшего взгляды пробудившейся реакции против закончившегося царствования, причем компилятор намеренно прикрылся громким именем историка. К Л. Ранке примкнул английский историк Бэри (Bury); гипотезу эту опроверг Нaury. Еще дальше Л. Ранке пошел А.К. Димитриу, совершенно отрицающий авторские права Прокопия. Памфлет, по его мнению, составлен из 2 самостоятельных частей; первая часть, направленная против Велисария, возникла в 548 г. под влиянием Нарзеса; вторая, направленная против Юстиниана и его жены Феодоры, написана в 559 г. и только внешним образом соединена с первой. В самое последнее время Б. Панченко снова пересмотрел историю вопроса и пришел к выводам, подтверждающим тонкий анализ Ф. Дана».

То, что сведения о работе А.К. Димитриу [8] вошли в Энциклопедический словарь Ф.А. Брокгауза и И.А. Ефрона [28], связано с тем, что А. Готлиб занимался византинистикой в Императорском Новороссийском университете под руководством Ф.И. Успенского в одно и то же время с А.К. Димитриу. В 1895 г. он переезжает в Санкт-Петербург, где специализируется на подготовке исторических статей для вышеуказанного словаря.

Совсем недавно открылись новые сведения по исследовательской византологической работе А.К. Димитриу в Одессе, найденные А. Музычко в делах фонда 45 Императорского Новороссийского университета Одесского областного государственного архива. Он пишет: «Все шансы стать византологическим «аспирантским» проектом Ф.И. Успенского имел А.К. Димитриу (1857-1925). От первого января 1892 г. до 1 марта 1894 г. он был сти- 
пендиантом по кафедре общей истории историко-филологического факультета Новороссийского университета. В этот период он развернул большой исследовательский темп. Два его византоведческих труда (один в области дипломатии, второй - в историографии (о творчестве Прокопия Кессарийского)) заметили современники (например, известный немецкий византинист К. Крумбахер и молодые исследователи). А.К. Димитриу сделал удачную карьеру педагога в средних учебных заведениях, но в науку так и не вернулся» [30].

В заключении А. Музычко указывает, что на труд А.К. Димитриу [7] рецензию дал в 1895 г. М. Грушевский [12], а также что локомотивами Одесского историко-филологического общества, кроме Ф.И. Успенского, были С. Пападимитриу, А. Пасловский, Ф. Режабек, А.К. Димитриу, Н.Г. Попов. При этом здесь шла ссылка о второй работе А.К. Димитриу [8].

Нам удалось подтвердить эти данные и несколько их расширить на основе изучения архивного дела РГИА (Санкт-Петербург), имеющиеся в нем документы позволяют судить о научных достижениях А.К. Димитриу. Так, например, при составлении для него ходатайства на получение профессорского звания Ф.И. Успенский особо подчеркнул его способности «К историческим мнениям», а также его «живое участие в специальных курсах» и мотивированное исполнение даваемых на дом работ: «Так, между прочим, им представлено было два реферата на 6 и 7 семестрах: 1) о борьбе светской власти и духовной в XIX веке; 2) о договорах Руси с греками» ${ }^{1}$.

А.К. Димитриу выполнил также работу на тему «Принципат Августа на основании Monumentum Ancyranum» под руководством профессора Э.Р. фон Штерна, в основу которой легли материалы, основанные на обширном изучении литературных источников на разных языках. Ф.И. Успенский подчеркивал, что А.К. Димитриу «с успехом овладел материалом и показал в достаточной степени критическую способность, что засвидетельствовала испытательная комиссия, оценив его работу высшей отметкой» ${ }^{2}$. Он же отмечал на необходимость дальнейших исследо-

\footnotetext{
${ }^{1}$ РГИА (Российский государственный исторический архив). Ф. 733. Оп. 150. Д. 729. Л. 102-103.

${ }^{2}$ Там же.
}

ваний А.К. Димитриу в области средневековой истории, а по окончании подготовки к профессорскому званию рекомендовал ему заняться подготовкой сборника византийсковенецианских договоров. Это согласуется с комментарием к работе А.К. Димитриу «К вопросу о договорах русских с греками» Ф.И. Успенского: «Передавая при сем факультету небольшую часть работы А.К. Димитриу по изучению означенных договоров, имею честь свидетельствовать, что она представляет оригинальную и не лишенную научного интереса попытку разрешить вопросы о подлинности русского договора с греками с точки зрения формы, содержания и процедуры договоров Византии и Венеции. Не может быть сомнений, что вопросы о договорах Руси с греками должны быть разрешены именно с этой стороны» ${ }^{3}$.

По поводу научных руководителей А.К. Димитриу следует сказать, что профессор Ф.И. Успенский (1845-1928) был крупнейшим византинистом своего времени, основателем и директором Русского археологического института в Константинополе, а профессор Э.Р. фон Штерн (1859-1924) являлся основателем Одесской школы археологии.

Итак, нами показано, что А.К. Димитриу, опубликовав 1894-1895 гг. всего две статьи по византинистике, внес существенный вклад в эту область исследований. На первую его статью, посвященную договорам русских с греками, до сих пор ссылаются крупнейшие ученые по византинистике и истории Древней Руси, а вторая его статья нашла отражение в статье о Прокопии, опубликованной известным византинистом А. Готлибом в Энциклопедическом словаре Ф.А. Брокгауза и И.А. Эфрона через четыре года после выхода статьи А.К. Димитриу. Нами показано, что последнее связано с тем, что А. Готлиб занимался византинистикой в Императорском Новороссийском университете под руководством Ф.И. Успенского одновременно с А.К. Димитриу. Изучение опубликованных исследований и архивных данных показало, что научными руководителями А.К. Димитриу являлись профессор Ф.И. Успенский (1845-1928), который был крупнейшим византинистом того времени и основателем Русского археологического института в Константинополе, и профессор Э.Р. фон Штерн

\footnotetext{
${ }^{3}$ Там же.
} 
(1859-1924), являвшийся основателем Одесской школы археологии.

\section{Список литературы}

1. Московкин В.M. Забытый деятель народного образования Курской и Воронежской губерний А.К. Димитриу как известный византинист // Научные ведомости Белгородского государственного университета. Серия История. Политология. Экономика. 2014. Т. 32. № 21 (192). C. 101-105.

2. Кривотулова Е.В. Развитие педагогического образования и педагогической науки в Воронежском университете // Роль классических университетов в педагогическом образовании: материалы Межрегион. науч.-практ. конф. Воронеж, 2003. С. 53-59.

3. Чернобаева Т.Н. К истории педагогического образования: Воронежский учительский институт (1913-1918 гг.) // Человек и общество: история и современность: Межвуз. сб. науч. тр. Воронеж, 2010. Вып. 9. С. 54-58.

4. Чернобаева T.H. У истоков высшего педагогического образования в Воронежской губернии // Вестник Костромского государственного университета им. Н.А. Некрасова. Серия Педагогика. Психология. Социальная работа. Ювенология. Социокинетика. 2007. Т. 13. C. 66-69.

5. Введенский А.М. Договоры Руси с греками Х в.: Клятва Святослава Игоревича // Труды отдела древнерусской литературы / Российская академия наук. Институт русской литературы (Пушкинский дом); отв. ред. О.В. Творогов. СПб.: Дмитрий Буланкин, 2006. Т. 57. $1002 \mathrm{c}$

6. Свердлов М.Б. Домонгольская Русь. Князь и княжеская власть на Руси VI - первой трети XIII вв. СПб.: Академический проект, 2003. $736 \mathrm{c.}$

7. Димитріу А. К вопросу о договорах русских с греками // Византийский временник. 1895. T. 3. C. 531-550.

8. Димитриу А.К. К вопросу о Historia Arcana // Летопись историко-филологического общества при Новороссийском университете. IV. Византийское отделение. II. Исследования. Одесса, 1894. С. 258-301.

9. Сахаров А.Н. Дипломатия Древней Руси: IX первая половина Х в. М.: Мысль, 1980.358 с.

10. Эверс И.Ф.Г. Древнейшее русское право в историческом его раскрытии / пер. с нем. И. Платонова. М., 1835.

11. Гедеонов С.А. Варяги и Русь: в 2 ч. Спб., 1876. Ч. 1. Варяги. 57 с.
12. Грушевский М. Рецензия на: Димитріу А. К вопросу о договорах русских с греками (Византийский временник. 1895. Т. 3. С. 531-550) // Записки Научного общества имени Шевченко. 1897. Т. 16. С. 3-4.

13. Звере Г. Древнейшее русское право в историческом его раскрытии. Спб., 1835. 135 с.

14. Ламбин Н.П. Действительно ли поход Олега под Царьград сказка? (Вопрос г. Иловайскому) // Журнал Министерства народного просвещения. 1873. № 7. С. 115-127.

15. Мейчик Д. Русско-византийские договоры // Журнал Министерства народного просвещения. Новая серия. 1915. Ч. 59. Октябрь. C. 296-297.

16. Памятники русского права / сост. А.А. Зимин. Вып. 1. М., 1952.

17. Срезневский И.И. О договорах Олега с греками // Известия Отделения русского языка и словесности. СПб., 1852. Т. 1. Вып. 7. С. 309 326.

18. Сергеевич В.И. Лекции и исследования по древней истории русского права. Спб., 1910. $635 \mathrm{c}$.

19. Шахматов А.А. Древнейшие судьбы русского племени. Пг., 1919.

20. Приселков М.Д. Русско-византийские отношения // Вестник древней истории. 1939. № 3.

21. Лонгинов А.В. Мирные договора русских с греками, заключенные в Х в. Одесса, 1904.

22. Самоквасов Д.Я. Древнее русское право. М., 1903.

23. Срезневский И.И. О договорах Олега с греками // Известия Отделения русского языка и словесности. СПб., 1852. Т. 2.

24. Лавровский $H$. О византийском элементе в языке договоров русских с греками. Спб., 1853.

25. Ламбин Н.П. О годе смерти Святослава Игоревича, великого князя Киевского // Записки Императорской Академии наук. Спб., 1876. C. $128-129$.

26. Греков Б.Д. Киевская Русь. М., 1949. 453 с.

27. Очерки истории СССР: в 9 т. Т. 3. Период феодализма IX-XV вв. Ч. 1. IX-XIII вв. Древняя Русь. Феодальная раздробленность / под ред. Б.Д. Грекова, Л.В. Черепина, В.Т. Пашуто. М., 1953.

28. Готлиб $A$. Прокопій - важнейшій историк ранней византійской эпохи // Энциклопедический словарь Ф.А. Брокгауза и И.А. Ефрона: в 86 т. Спб., 1898. Т. 25 (49). С. 387-388.

29. Погодин М.П. Исследования, замечания и лекции: в 7 т. Т. 3. М., 1846.

30. Музичко $O$. Розвиток візантиністики в історіографічному процесі на території 
Південної України наприкінці XIX - на початку XX ст. // Наукові зошити історичного факультету Львівського університету. 2016. Вип. 17. С. 127-133.
Поступила в редакцию 18.05.2017 г.

Отрецензирована 11.06.2017 г.

Принята в печать 03.11.2017 г.

Конфликт интересов отсутствует.

\title{
Информация об авторах
}

Московкин Владимир Михайлович, доктор географических наук, профессор, профессор кафедры мировой экономики. Белгородский государственный национальный исследовательский университет, г. Белгород, Российская Федерация. E-mail: moskovkin@bsu.edu.ru

Садовски Марина Владимировна, кандидат философских наук, доцент, доцент кафедры дошкольного и специального (дефектологического) образования. Белгородский государственный национальный исследовательский университет, г. Белгород, Российская Федерация. E-mail: sadovski@bsu.edu.ru

Для корреспонденции: Московкин B.M., e-mail: moskovkin@bsu.edu.ru

Московкин В.М., Садовски М.В. О вкладе бывшего директора Белгородского и Воронежского учительских институтов А.К. Димитриу (1857-1925) в византинистику // Вестник Тамбовского университета. Серия Гуманитарные науки. Тамбов, 2018. Т. 23. Вып. 1 (171). С. 115-123. DOI: 10.20310/1810-0201-2018-23-1(171)-115-123.

DOI: $10.20310 / 1810-0201-2018-23-1(171)-115-123$

\begin{abstract}
ABOUT THE CONTRIBUTION OF THE FORMER DIRECTOR OF BELGOROD AND VORONEZH TEACHERS' INSTITUTES A.K. DIMITRIU (1857-1925) IN THE BYZANTINE STUDIES
\end{abstract}

\author{
Vladimir Mikhaylovich MOSKOVKIN, Marina Vladimirovna SADOVSKI \\ Belgorod National Research University \\ 85 Pobedy St., Belgorod 308015, Russian Federation \\ E-mail: moskovkin@bsu.edu.ru
}

\begin{abstract}
Scientific contribution of the former director of Belgorod and Voronezh Teacher's Institutes Alexey Konstantinovich Dimitriu (1857-1925) in the Byzantine studies is considered. As a result of the analysis of literature sources the authors show the significance of the works of A.K. Dimitriu dedicated to the Russian contracts with the Greeks and the work of Procopius of Caesarea "The Secret History", which is still referenced by most prominent scientists - byzantinists and experts on the history of Ancient Russia. The works of well-known researchers on the history of Ancient Russia and Byzantium A.M. Vvedensky, M.B. Sverdlov, A.N. Sakharov, A. Gotlib are studied. Special attention is paid to the fundamental labour of A.K. Dimitriu, published in Odessa in 1894 and dedicated to "The Secret History" of Procopius of Caesarea - the prominent historian of the early Byzantine era. The importance of the above-mentioned works of A.K. Dimitriu, consisting in the fact that in four years after its release, it has been cited in the article of A. Gottlieb "Procopius the Historian", printed in the Encyclopedic Dictionary of F.A. Brockhaus and I.A. Efron is highlighted. The research of the published studies and archival data shows that the scientific supervisors to A.K. Dimitriu were major byzantinists of that time Professor F.I. Uspensky and E.R. von Stern.

Keywords: A.K. Dimitriu; Belgorod Teacher's Institute; Voronezh Teacher's Institute; Byzantine studies; contract between the Russians and Greeks; Procopius
\end{abstract}

\section{References}

1. Moskovkin V.M. Zabytyy deyatel' narodnogo obrazovaniya Kurskoy i Voronezhskoy guberniy A.K. Dimitriu kak izvestnyy vizantinist [The forgotten public education worker of Kursk and Voronezh provinces A.K. Dimitriu as a famous 
Byzantinist]. Nauchnye vedomosti Belgorodskogo gosudarstvennogo universiteta. Seriya Istoriya. Politologiya. Ekonomika [Scientific Journal of Belgorod State University. Series History. Politology. Economics], 2014, vol. 32, no. 21 (192), pp. 101-105. (In Russian).

2. Krivotulova E.V. Razvitie pedagogicheskogo obrazovaniya i pedagogicheskoy nauki v Voronezhskom universitete [The development of pedagogic education and pedagogic science in Voronezh University]. Materialy Mezhregionalnoy nauchno-prakticheskoy konferentsii «Rol' klassicheskikh universitetov v pedagogicheskom obrazovanii» [Proceedings of Interregional Scientific-Practical Conference "The Role of Classical Universities in Pedagogic Education"]. Voronezh, 2003, pp. 53-59. (In Russian).

3. Chernobaeva T.N. K istorii pedagogicheskogo obrazovaniya: Voronezhskiy uchitelskiy institut (1913-1918 gg.) [On the history of pedagogic education: Voronezh Teachers' Institute (1913-1918)]. Mezhvuzovskiy sbornik nauchnykh trudov "Chelovek i obshchestvo: istoriya i sovremennost'» [Interacademic Collection of Scientific Works "Human and Society: History and Modernity"]. Voronezh, 2010, no. 9, pp. 54-58. (In Russian).

4. Chernobaeva T.N. U istokov vysshego pedagogicheskogo obrazovaniya v Voronezhskoy gubernii [At the origins of higher pedagogic education in Voronezh province]. Vestnik Kostromskogo gosudarstvennogo universiteta im. N.A. Nekrasova. Seriya Pedagogika. Psikhologiya. Sotsial'naya rabota. Yuvenologiya. Sotsiokinetika [A Herald of Nekrasov Kostroma State University. Series Pedagogy. Psychology. Social Work. Juvenology. Social Kinetics], 2007, vol. 13, pp. 66-69. (In Russian).

5. Vvedenskiy A.M. Dogovory Rusi s grekami X v.: Klyatva Svyatoslava Igorevicha [Treaties of Rus with the Greeks in 10th century: oath of Svyatoslav Igorevich]. In: Tvorogov O.V. (executive ed.). Trudy otdela drevnerusskoy literatury [Proceedings of Ancient Russian Literature Department]. St. Petersburg, Dmitriy Bulankin's Publ., 2006, vol. 57, 1002 p. (In Russian).

6. Sverdlov M.B. Domongol'skaya Rus'. Knyaz' i knyazheskaya vlast' na Rusi VI-pervoy treti XIII vv. [Pre-Mongolian Rus. Prince and Princely Power in Russia in 6th - the First Third of 13th Century]. St. Petersburg, Akademicheskiy proekt Publ., 2003, 736 p. (In Russian).

7. Dimitriu A. K voprosu o dogovorakh russkikh s grekami [On the issue of Russians and Greeks' treaties]. Vizantiyskiy vremennik [Byzantian Chronicle], 1895, vol. 3, pp. 531-550. (In Russian).

8. Dimitriu A.K. K voprosu o Historia Arcana [On the issue of Historia Arcana]. Letopis' istoriko-filologicheskogo obshchestva pri Novorossiyskom universitete. IV. Vizantiyskoe otdelenie. II. Issledovaniya [Chronicle of Historico-Philological Community in Novorossiysk University. 4. Byzantian Department. 2. Researches]. Odessa, 1894, pp. 258-301. (In Russian).

9. Sakharov A.N. Diplomatiya Drevney Rusi: IX-pervaya polovina Xv. [Diplomacy of Ancient Rus: 9th - the First Half of 10th Century]. Moscow, Mysl Publ., 1980, 358 p. (In Russian).

10. Evers I.F.G. Drevneyshee russkoe pravo v istoricheskom ego raskrytii [The Most Ancient Russian Law in Its Historic Revelation]. Moscow, 1835. (In Russian).

11. Gedeonov S.A. Varyagi i Rus'. Ch. 1. Varyagi [The Varangians and Rus. Part 1. Varangians]. St. Petersburg, 1876, 57 p. (In Russian).

12. Grushevskiy M. Retsenziya na: Dimitriu A. K voprosu o dogovorakh russkikh s grekami (Vizantiyskiy vremennik. 1895. T. 3. S. 531-550) [Review on: Dimitriu A. On the issue of Russians and Greeks' treaties (Byzantian chronicle. 1895. Vol. 3. Pp. 531-550)]. Zapiski Nauchnogo obshchestva imeni Shevchenko [Notes of Shevchenko Scientific Society], 1897, vol. 16, pp. 3-4. (In Russian).

13. Zvere G. Drevneyshee russkoe pravo v istoricheskom ego raskrytii [The Earliest Russian Law in Its Historical Revelation]. St. Petersburg, 1835, 135 p. (In Russian).

14. Lambin N.P. Deystvitel'no li pokhod Olega pod Tsar'grad skazka? (Vopros g. Ilovayskomu) [Is Oleg's campaign for Tsarigrad a fairytale? (Question to Mr. Ilovaisky)]. Zhurnal Ministerstva narodnogo prosveshcheniya [Journal of Ministry of National Education], 1873, no. 7, pp. 115-127. (In Russian).

15. Meychik D. Russko-vizantiyskie dogovory [Russian and Byzantian treaties]. Zhurnal Ministerstva narodnogo prosveshcheniya. Novaya seriya [Journal of Ministry of National Education. New Series], 1915, part 59, October, pp. 296-297. (In Russian).

16. Zimin A.A. (compiler). Pamyatniki russkogo prava [Memorials of Russian Law]. Moscow, 1952, no. 1. (In Russian).

17. Sreznevskiy I.I. O dogovorakh Olega s grekami [About the contracts of Oleg with the Greeks]. Izvestiya Otdeleniya russkogo yazyka i slovesnosti [News of Russian Language and Literature Department]. St. Petersburg, 1852, vol. 1, no. 7, pp. 309-326. (In Russian).

18. Sergeevich V.I. Lektsii i issledovaniya po drevney istorii russkogo prava [Lectures and Researches in Ancient History of Russian Law]. St. Petersburg, 1910, 635 p. (In Russian).

19. Shakhmatov A. A. Drevneyshie sud'by russkogo plemeni [The Most Ancient Destinies of Russian Tribe]. Petrograd, 1919. (In Russian).

20. Priselkov M.D. Russko-vizantiyskie otnosheniya [Russian-Byzantian relations]. Vestnik drevney istorii [Herald of Ancient History], 1939, no. 3. (In Russian).

21. Longinov A.V. Mirnye dogovora russkikh s grekami, zaklyuchennye $v X v$. [Treaty of Peace among the Russians and the Greeks, Made in 10th Century]. Odessa, 1904. (In Russian).

22. Samokvasov D.Y. Drevnee russkoe pravo [Ancient Russian Law]. Moscow, 1903. (In Russian).

23. Sreznevskiy I.I. O dogovorakh Olega s grekami [About the treaties of Oleg with the Greeks]. Izvestiya Otdeleniya russkogo yazyka i slovesnosti [News of Russian Language and Literature Department]. St. Petersburg, 1852, vol. 2. (In Russian). 
24. Lavrovskiy N. O vizantiyskom elemente v yazyke dogovorov russkikh s grekami [About Byzantian Element in the Language of Russians and Greeks' Treaties]. St. Petersburg, 1853. (In Russian).

25. Lambin N.P. O gode smerti Svyatoslava Igorevicha, velikogo knyazya Kievskogo [About the year of death of Svyatoslav Igorevich, the great prince of Kiev]. Zapiski Imperatorskoy Akademii nauk [Proceedings of Emperor's Academy of Sciences], 1876, pp. 128-129. (In Russian).

26. Grekov B.D. Kievskaya Rus' [Kievan Russia]. Moscow, 1949, 453 p. (In Russian).

27. Grekova B.D., Cherepina L.V., Pashuto V.T. (eds.). Ocherki istorii SSSR. T. 3. Period feodalizma IX-XV vv. Ch. I. IXXIII vv. Drevnyaya Rus'. Feodal'naya razdroblennost' [Outlines of the USSR History. Vol. 3. The Period of Feudalism in 9-15th Centuries. Part 1. 9-13th Centuries. Ancient Rus. Feudal Fragmentation]. Moscow, 1953. (In Russian).

28. Gotlib A. Prokopiy - vazhneyshiy istorik ranney vizantiyskoy epokhi [Procopius - the most important historian of early Byzantium epoch]. Entsiklopedicheskiy slovar' F.A. Brokgauza i I.A. Efrona [Brockhaus and Efron Encyclopedic Dictionary]. St. Petersburg, 1898, vol. 25 (49), pp. 387-388. (In Russian).

29. Pogodin M.P. Issledovaniya, zamechaniya i lektsii [Researches, Remarks and Lectures]. Moscow, 1846, vol. 3. (In Russian).

30. Muzychko O. Rozvytok vizantynistyky v istoriografichnomu procesi na terytorii' Pivdennoi' Ukrai'ny naprykinci XIX na pochatku XX st. Naukovi zoshyty istorychnogo fakul'tetu L'vivs'kogo universytetu, 2016, no. 17, pp. 127-133. (In Ukrainian).

Received 18 May 2017

Reviewed 11 June 2017

Accepted for press 3 November 2017

There is no conflict of interests.

\section{Information about the authors}

Moskovkin Vladimir Mikhaylovich, Doctor of Geography, Professor, Professor of World Economy Department. Belgorod National Research University, Belgorod, Russian Federation. E-mail: moskovkin@bsu.edu.ru

Sadovski Marina Vladimirovna, Candidate of Philosophy, Associate Professor, Associate Professor of Preschool and Special (Defectology) Education Department. Belgorod National Research University, Belgorod, Russian Federation. E-mail: sadovski@bsu.edu.ru

For correspondence: Moskovkin V.M., e-mail: moskovkin@bsu.edu.ru

\section{For citation}

Moskovkin V.M., Sadovski M.V. O vklade byvshego direktora Belgorodskogo i Voronezhskogo uchitel'skikh institutov A.K. Dimitriu (1857-1925) v vizantinistiku [About the contribution of the former director of Belgorod and Voronezh Teachers' Institutes A.K. Dimitriu (1857-1925) in the Byzantine studies]. Vestnik Tambovskogo universiteta. Seriya Gumanitarnye nauki - Tambov University Review. Series: Humanities, 2018, vol. 23, no. 1 (171), pp. 115-123. DOI: 10.20310/1810-02012018-23-1(171)-115-123. (In Russian, Abstr. in Engl.). 